Article

\title{
In Silico Study and Bioprospection of the Antibacterial and Antioxidant Effects of Flavone and Its Hydroxylated Derivatives
}

\author{
Camila de Albuquerque Montenegro ${ }^{1,2, *}$, Gregório Fernandes Gonçalves ${ }^{1}$, \\ Abrahão Alves de Oliveira Filho ${ }^{3}$, Andressa Brito Lira ${ }^{1}$, Thays Thyara Mendes Cassiano ${ }^{2}$, \\ Natanael Teles Ramos de Lima ${ }^{2}$, José Maria Barbosa-Filho ${ }^{1,4}$, \\ Margareth de Fátima Formiga Melo Diniz ${ }^{1,4}$ and Hilzeth Luna Freire Pessôa 5 \\ 1 Postgraduate Program in Natural Products and Synthetic Bioactive, Federal University of Paraiba, \\ João Pessoa 58033-455, Paraíba, Brazil; gregorio_goncalves@yahoo.com.br (G.F.G.); \\ andressabritolira@hotmail.com (A.B.L.); jbarbosa@ltf.ufpb.br (J.M.B.-F.); \\ margareth@reitoria.ufpb.br (M.d.F.F.M.D.) \\ 2 Department of Pharmacy, Center Biological Sciences and Health, State University of Paraiba, Campina \\ Grande 58429-600, Paraíba, Brazil; thaysthyaracg@hotmail.com (T.T.M.C.); \\ teles.natanael@gmail.com (N.T.R.d.L.) \\ 3 Academic Biological Science Unit, Health Center and Rural Technology, Federal University of Campina \\ Grande, Patos 58708-110, Paraíba, Brazil; abrahao.farm@gmail.com \\ 4 Department of Pharmaceutical Sciences, Health Sciences Center, Federal University of Paraiba, João Pessoa \\ 58059-900, Paraíba, Brazil \\ 5 Department of Molecular Biology, Center of Exact Sciences and Nature, Federal University of Paraíba, João \\ Pessoa 58051-090, Paraíba, Brazil; hilzeth@gmail.com \\ * Correspondence: camontenegro2502@gmail.com; Tel.: +55-83-3315-3353
}

Academic Editor: Diego Muñoz-Torrero

Received: 28 March 2017; Accepted: 20 May 2017; Published: 24 May 2017

\begin{abstract}
Flavonoid compounds are widely used as natural protective species, which can act as anti-inflammatory, antioxidant, anticoagulant, antihypertensive and antitumor agents. This study set out to investigate the probable pharmacological activities, along with the antibacterial and antioxidant effects, of flavone and its hydroxy derivatives: 3-hydroxyflavone, 5-hydroxyflavone and 6-hydroxyflavone. To do so, we investigated their pharmacological characteristics, using in silico tests that indicate likelihood of activity or inactivity, with the PASS online software, and the antimicrobial potential against Gram positive and Gram negative bacteria was also analyzed, including bacteria of clinical importance. We also tested for oxidant and antioxidant potential in these molecules in the presence of reactive oxygen species (ROS) and phenylhydrazine ( $\mathrm{Ph}$ ). The results revealed the following characteristics: pharmacological activities for the flavonoids as agonists of cell membrane integrity and as permeability inhibitors, as antagonists of anaphylatoxin receptors, as inhibitors of both kinase and peroxidase, and as having both antimutagenic capacity and vaso-protective potential. All of the flavonoids exhibited moderate antibacterial activity against Gram positive and Gram negative strains, with the flavones being bactericidal at $200 \mu \mathrm{g} / \mathrm{mL}$ for the strains of P. aeruginosa ATCC 8027, S. aureus ATCC 25619 and E. coli 104; the other flavonoids revealed bacteriostatic action. The substances did not promote erythrocyte oxidation and behaved as sequestrators and antioxidants of hydrogen peroxide $\left(\mathrm{H}_{2} \mathrm{O}_{2}\right)$ and phenylhydrazine $(\mathrm{Ph})$. It was concluded that the analyzed compounds have various pharmacological activities in accordance with the predictions of PASS online, as their antibacterial and antioxidant activities were confirmed. The study also helps to consolidate the use of computational chemistry in silico tools to guide new drug search and discovery protocols.
\end{abstract}


Keywords: flavonoids; PASS online; antibacterials; antioxidants

\section{Introduction}

Flavonoids are the most common group of polyphenolic compounds and are found in a huge variety of plants [1]. They feature low molecular weight and exert effects such as modulating reactive oxygen species (ROS) levels, influencing the plant hormone auxin's transport, and act on defense mechanisms and allelopathy [2]. They are divided into the following classes according to substitutions: flavones, flavonols, chalcones, aurones, flavanones, isoflavones, catechins and anthocyanidins. Flavones and flavonols are biosynthetically produced. It can be said that the flavonols are flavones with a hydroxyl substitute in position C3. Their analysis, synthesis, and reactions share therefore a common theoretical basis [3].

Several studies have demonstrated that flavones have anticancer activity [4-7], antioxidant [8-10], antitumor [11-13], anti-inflammatory [9,14-16], cardioprotective [8,17,18]; antiviral [19-21], neuroprotective [7,9], antibacterial [22-24], and induction of apoptosis in leukemic malignant cells [25]. These biological activities depend on the chemical structure and the various substituents that these molecules have; the basic backbone can undergo a number of modifications, such as glycosylation, esterification, amidation, and hydroxylation, among others that modulate the polarity, toxicity and intracellular actions of these compounds [26].

Software for in silico screening is intended to perform virtual study of molecules, and includes tools that predict theoretical selectivity and recognition for a given site of action or bioreaction, and are generally associated with large databases of small molecules for structural comparison [27-29]. Computational prediction models, also called predictive tools, play a prominent role in the repertoire of methodologies guiding pharmaceutical technological research. These devices are used to study existing and hypothetical substances, predicting results of pharmacological, pharmacokinetic and toxicological behavior [30,31]. Such predictive tools have already been recommended by regulatory agencies for studies of technological development in order to verify the theoretical toxicity of substances in the mammalian metabolic environment [32], in addition to allowing the creation of a database of relations between chemical structure and biological activity (SAR) [33].

The objective of this work was to perform in silico screening of theoretical pharmacological, pharmacokinetic, and toxicological activities as well as to investigate the antibacterial, oxidant and antioxidant effects of flavone, 3-hydroxyflavone, 5-hydroxyflavone and 6-hydroxyflavone (Figure 1); evidencing the relationship between chemical structure and observed pharmacological effect, and consolidating the use of computational chemistry to characterize substances with therapeutic potential.<smiles>O=c1cc(-c2ccccc2)oc2ccccc12</smiles>

Flavone<smiles>O=c1c(O)c(-c2ccccc2)oc2ccccc12</smiles>

3-hydroxyflavone<smiles>O=c1cc(-c2ccccc2)oc2cccc(O)c12</smiles>

5-hydroxyflavone<smiles>O=c1cc(-c2ccccc2)oc2ccc(O)cc12</smiles>

6-hydroxyflavone

Figure 1. Structure of flavone and its hydroxylated derivatives.

\section{Results}

\subsection{In Silico Tests-PASS Online}

The online tool "PASS" provided possible biological activities for flavone, 3-hydroxyflavone, 5-hydroxyflavone, and 6-hydroxyflavone; and the results are respectively expressed in Tables 1-4. For flavone, 37 potential biological activities were suggested; with $\mathrm{Pa} \geq 78.7 \%$ (Pa being the probability 
"to be active") (Table 1). For 3-hydroxyflavone, PASS revealed 39 likely biological activities with Pa $\geq 79.8 \%$ (Table 2 ). For the other hydroxylated flavonoids 5-hydroxyflavone and 6-hydroxyflavone, Tables 3 and 4 respectively present 47 and 49 activity suggestions with respective Pa values of $\mathrm{Pa} \geq$ $79.5 \%$, and $\mathrm{Pa} \geq 79.7 \%$.

Among the various biological possibilities, for all the flavonoids analyzed probable agonistic action towards cell membrane integrity and inhibition of membrane permeability; a probable inhibition of kinases; a strong antimutagenic activity and metabolic influence on cytochrome P450 enzyme complexes, at times behaving as a substrate, at other times as an enzymatic inducer were indicated. In addition: inhibition of the enzymes peroxidase and oxidoreductase, and vasoprotective potential was assigned to flavone, 5-hydroxyflavone and 6-hydroxyflavone, while separately, for 5-hydroxyflavone and 6-hydroxyflavone, antitumor potential via inhibition of the Pin1 gene and increased expression of the TP53 gene was indicated.

Table 1. Suggestions of biological activities for flavone at $\mathrm{Pa}>78.7 \%$-second analysis by PASS online tool.

\begin{tabular}{|c|c|c|}
\hline PA & PI & Activity \\
\hline 0.952 & 0.001 & Inhibitor of 4-nitrophenol 2-monooxygenase \\
\hline 0.952 & 0.003 & HIF1A expression inhibitor \\
\hline 0.947 & 0.004 & Agonist of membrane integrity \\
\hline 0.943 & 0.002 & Inhibitor 27 -hydroxycholesterol $7 \alpha$-monooxygenas \\
\hline 0.938 & 0.002 & Kinase inhibitor \\
\hline 0.933 & 0.002 & Inhibitor of colestanetriol 26-monooxygenase \\
\hline 0.929 & 0.003 & Anaphylatoxin receptor antagonist \\
\hline 0.914 & 0.003 & Inhibitor of membrane permeability \\
\hline 0.913 & 0.004 & Chlordecone reductase inhibitor \\
\hline 0.913 & 0.009 & CYP2C12 substrate \\
\hline 0.903 & 0.002 & CYP2B5 substrate \\
\hline 0.895 & 0.002 & Aryl-alcohol dehydrogenase $\left(\mathrm{NADP}^{+}\right)$inhibitor \\
\hline 0.893 & 0.002 & CYP1A2 inducer \\
\hline 0.874 & 0.014 & Aspulvinone dimethylallyltransferase inhibitor \\
\hline 0.872 & 0.002 & Inhibitor of P-benzoquinone reductase (NADPH) \\
\hline 0.857 & 0.004 & Inhibitor of 2-dehydropantoate 2-reductase \\
\hline 0.857 & 0.006 & Aldehyde oxidase inhibitor \\
\hline 0.854 & 0.003 & CYP1A inducer \\
\hline 0.850 & 0.012 & Methylenetetrahydrofolate reductase inhibitor (NADPH) \\
\hline 0.849 & 0.004 & Vasoprotector \\
\hline 0.848 & 0.002 & CYP2A4 substrate \\
\hline 0.829 & 0.002 & Quercetin 2.3-dioxygenase inhibitor \\
\hline 0.829 & 0.002 & Inhibitor of Leukotriene-B4 20-monooxygenase \\
\hline 0.820 & 0.005 & Inhibitor of complement factor D \\
\hline 0.819 & 0.005 & Alkane 1-monooxygenase inhibitor \\
\hline 0.814 & 0.003 & CYP2A11 substrate \\
\hline 0.813 & 0.018 & CYP2J substrate \\
\hline 0.813 & 0.022 & Testosterone 17beta-dehydrogenase $\left(\mathrm{NADP}^{+}\right)$inhibitor \\
\hline 0.809 & 0.002 & CYP1A1 inducer \\
\hline 0.807 & 0.003 & MAP kinase stimulant \\
\hline 0.806 & 0.006 & Inhibitor of oxidoreductase \\
\hline 0.804 & 0.005 & Peroxidase inhibitor \\
\hline 0.803 & 0.003 & Total ecdysone 20-monooxygenase inhibitor \\
\hline 0.801 & 0.004 & Inhibitor of Pin1 \\
\hline 0.800 & 0.018 & mucous membrane protector \\
\hline 0.795 & 0.004 & Antimutagenic \\
\hline 0.787 & 0.006 & Inhibitor of nitrate reductase (cytochrome) \\
\hline
\end{tabular}

$\mathrm{Pa}=($ probability "to be active"), $\mathrm{Pi}=$ (probability "to be inactive"). 
Table 2. Suggestions of biological activities for 3-hydroxyflavone at $\mathrm{Pa}>79.8 \%$-second analysis by PASS online tool.

\begin{tabular}{|c|c|c|}
\hline PA & PI & Activity \\
\hline 0.962 & 0.003 & Agonist of membrane integrity \\
\hline 0.957 & 0.003 & HIF1A expression inhibitor \\
\hline 0.954 & 0.002 & Chlordecone reductase inhibitor \\
\hline 0.947 & 0.001 & Aryl-alcohol dehydrogenase $\left(\mathrm{NADP}^{+}\right)$inhibitor \\
\hline 0.947 & 0.002 & Kinase inhibitor \\
\hline 0.939 & 0.003 & Inhibitor of membrane permeability \\
\hline 0.938 & 0.001 & Inhibitor of $p$-benzoquinone reductase (NADPH) \\
\hline 0.929 & 0.001 & Quercetin 2.3-dioxygenase inhibitor \\
\hline 0.922 & 0.002 & Inhibitor of 2-dehydropantoate 2-reductase \\
\hline 0.917 & 0.002 & Peroxidase inhibitor \\
\hline 0.896 & 0.009 & Aspulvinone dimethylallyltransferase inhibitor \\
\hline 0.896 & 0.013 & CYP2C12 substrate \\
\hline 0.894 & 0.002 & MAP kinase stimulant \\
\hline 0.893 & 0.002 & CYP1A inducer \\
\hline 0.892 & 0.002 & Colestanetriol inhibitor 26-monooxygenase \\
\hline 0.889 & 0.002 & 2-Enoate reductase inhibitor \\
\hline 0.888 & 0.002 & Inhibitor of 4-nitrophenol 2-monooxygenase \\
\hline 0.888 & 0.007 & Inhibitor ubiquinol, cytochrome-c reductase \\
\hline 0.880 & 0.005 & CYP1A substrate \\
\hline 0.877 & 0.003 & Inhibitor of alcohol dehydrogenase $\left(\mathrm{NADP}^{+}\right)$ \\
\hline 0.876 & 0.002 & Inhibitor of NADPH-ferrihemoprotein reductase \\
\hline 0.870 & 0.003 & Antimutagenic \\
\hline 0.870 & 0.003 & Inhibitor 27 -hydroxycholesterol $7 \alpha$-monooxygenase \\
\hline 0.861 & 0.002 & CYP1A1 inducer \\
\hline 0.859 & 0.007 & Enhances expression of TP53 \\
\hline 0.856 & 0.011 & Methylenetetrahydrofolate reductase inhibitor (NADPH) \\
\hline 0.843 & 0.004 & CYP1A1 substrate \\
\hline 0.843 & 0.008 & Anaphylatoxin receptor antagonist \\
\hline 0.837 & 0.001 & Inhibitor of glycerol dehydrogenase $\left(\mathrm{NADP}^{+}\right)$ \\
\hline 0.827 & 0.003 & Enhances expression of HMOX1 \\
\hline 0.825 & 0.005 & CYP1A2 substrate \\
\hline 0.819 & 0.004 & UGT1A9 substrate \\
\hline 0.816 & 0.002 & Inhibitor of 2-dehydropantolactone reductase (A-specific) \\
\hline 0.804 & 0.009 & Inhibitor dehydro-L-gulonate decarboxylase \\
\hline 0.802 & 0.003 & Inhibitor of $\beta$-carotene 15.15 -monooxygenase \\
\hline 0.800 & 0.005 & Inhibitor of nitrate reductase (cytochrome) \\
\hline 0.800 & 0.008 & Agonist of apoptosis \\
\hline 0.799 & 0.006 & Alkane 1-monooxygenase inhibitor \\
\hline 0.798 & 0.021 & The substrate CYP2J \\
\hline
\end{tabular}

$\mathrm{Pa}=($ probability "to be active" $), \mathrm{Pi}=($ probability "to be inactive"). 
Table 3. Suggestions of biological activities for 5-hydroxyflavone at $\mathrm{Pa}>79.5 \%$-second analysis by PASS online tool.

\begin{tabular}{|c|c|c|}
\hline PA & PI & Activity \\
\hline 0.963 & 0.003 & Agonist of membrane integrity \\
\hline 0.956 & 0.002 & Chlordecone reductase inhibitor \\
\hline 0.953 & 0.003 & HIF1A expression inhibitor \\
\hline 0.942 & 0.005 & Substrate of CYP2C12 \\
\hline 0.937 & 0.003 & Inhibitor of membrane permeability \\
\hline 0.935 & 0.002 & Kinase inhibitor \\
\hline 0.934 & 0.003 & Anaphylatoxin receptor antagonist \\
\hline 0.930 & 0.001 & Aryl alcohol dehydrogenase inhibitor $\left(\mathrm{NADP}^{+}\right)$ \\
\hline 0.923 & 0.004 & Aldehyde oxidase inhibitor \\
\hline 0.921 & 0.002 & Inhibitor of P-benzoquinone reductase (NADPH) \\
\hline 0.920 & 0.003 & Inhibitor 2-dehydropantoate 2-reductase \\
\hline 0.909 & 0.002 & Inhibitor of 4-nitrophenol 2-monooxygenase \\
\hline 0.904 & 0.002 & Colestanetriol 26-monooxygenase inhibitor \\
\hline 0.903 & 0.001 & Quercetin 2.3-dioxygenase inhibitor \\
\hline 0.901 & 0.003 & Vasoprotector \\
\hline 0.900 & 0.008 & Aspulvinone dimethylallyltransferase inhibitor \\
\hline 0.897 & 0.002 & CYP1A inducer \\
\hline 0.897 & 0.002 & Histidine kinase inhibitor \\
\hline 0.895 & 0.003 & Inhibitor 27-hydroxycholesterol $7 \alpha$-monooxygenase \\
\hline 0.888 & 0.003 & Peroxidase inhibitor \\
\hline 0.887 & 0.008 & Inhibitor of ubiquinol-cytochrome-c reductase \\
\hline 0.882 & 0.002 & Antimutagenic \\
\hline 0.880 & 0.002 & Inhibitor of NADPH-ferrihemoprotein reductase \\
\hline 0.878 & 0.005 & CYP1A substrate \\
\hline 0.871 & 0.007 & Enhances expression of TP53 \\
\hline 0.868 & 0.002 & CYP1A1 inducer \\
\hline 0.864 & 0.004 & UGT1A6 substrate \\
\hline 0.854 & 0.003 & Inhibitor of alcohol dehydrogenase $\left(\mathrm{NADP}^{+}\right)$ \\
\hline 0.849 & 0.002 & 2-Enoate reductase inhibitor \\
\hline 0.847 & 0.004 & Alkane 1-monooxygenase inhibitor \\
\hline 0.842 & 0.003 & Enhances expression of HMOX1 \\
\hline 0.841 & 0.002 & Inhibitor of $\beta$-carotene $15.15^{\prime}$-monooxygenase \\
\hline 0.840 & 0.004 & UGT1A9 substrate \\
\hline 0.838 & 0.001 & Inhibitor of glycerol dehydrogenase $\left(\mathrm{NADP}^{+}\right)$ \\
\hline 0.838 & 0.012 & Anti-seborrheic \\
\hline 0.837 & 0.005 & CYP1A1 substrate \\
\hline 0.835 & 0.003 & CYP2B5 substrate \\
\hline 0.830 & 0.003 & CYP2A4 substrate \\
\hline 0.827 & 0.003 & Inhibitor of Pin1 \\
\hline 0.818 & 0.002 & SULT1A3 substrate \\
\hline 0.814 & 0.008 & Inhibitor dihydrocholic L-gulonate decarboxylase \\
\hline 0.812 & 0.002 & Inhibitor of Leukotriene-B4 20-monooxygenase \\
\hline 0.807 & 0.008 & Agonist of apoptosis \\
\hline 0.806 & 0.003 & Inhibitor of histamine release \\
\hline 0.804 & 0.003 & Inhibitor of nitrite reductase $[\mathrm{NAD}(\mathrm{P}) \mathrm{H}]$ \\
\hline 0.802 & 0.002 & Inhibitor 2-dehydropantolactone reductase (A-specific) \\
\hline 0.795 & 0.003 & MAP kinase stimulant \\
\hline
\end{tabular}


Table 4. Suggestions of biological activities for 6-hydroxyflavone at $\mathrm{Pa}>79.2 \%$-second analysis by PASS online tool.

\begin{tabular}{|c|c|c|}
\hline PA & PI & Activity \\
\hline 0.957 & 0.003 & Agonist of membrane integrity \\
\hline 0.949 & 0.002 & Chlordecone reductase inhibitor \\
\hline 0.948 & 0.004 & HIF1A expression inhibitor \\
\hline 0.945 & 0.004 & CYP2C12 substrate \\
\hline 0.935 & 0.003 & Inhibitor of membrane permeability \\
\hline 0.932 & 0.001 & Aryl alcohol dehydrogenase inhibitor $\left(\mathrm{NADP}^{+}\right)$ \\
\hline 0.932 & 0.001 & Inhibitor of 4-nitrophenol 2-monooxygenase \\
\hline 0.929 & 0.003 & Inhibitor aldehyde oxidase \\
\hline 0.924 & 0.002 & Inhibitor of $p$-benzoquinone reductase (NADPH) \\
\hline 0.915 & 0.002 & Inhibitor colestanetriol 26-monooxygenase \\
\hline 0.914 & 0.003 & Kinase inhibitor \\
\hline 0.907 & 0.002 & Inhibitor 27-Hydroxycolesterol $7 \alpha$-monooxygenase \\
\hline 0.901 & 0.003 & Inhibitor 2-2-dehydropantoate reductase \\
\hline 0.895 & 0.004 & Anaphylatoxin receptor antagonist \\
\hline 0.894 & 0.002 & CYP1A inducer \\
\hline 0.892 & 0.003 & Peroxidase inhibitor \\
\hline 0.888 & 0.002 & Antimutagenic \\
\hline 0.887 & 0.011 & Aspulvinone dimethylallyltransferase inhibitor \\
\hline 0.884 & 0.002 & MAP kinase stimulant \\
\hline 0.880 & 0.001 & Quercetin 2.3-dioxygenase inhibitor inhibitor \\
\hline 0.875 & 0.006 & Anti-seborreic \\
\hline 0.868 & 0.002 & CYP1A1 inducer \\
\hline 0.852 & 0.007 & Enhances expression of TP53 \\
\hline 0.851 & 0.005 & CYP1A substrate \\
\hline 0.850 & 0.003 & Inhibitor of NADPH-ferrihemoprotein reductase \\
\hline 0.850 & 0.003 & CYP2B5 substrate \\
\hline 0.844 & 0.003 & Enhances expression of HMOX1 \\
\hline 0.843 & 0.003 & CYP2A4 substrate \\
\hline 0.843 & 0.004 & UGT1A9 substrate \\
\hline 0.840 & 0.003 & Inhibitor of Pin1 \\
\hline 0.840 & 0.004 & Vasoprotector \\
\hline 0.841 & 0.005 & Expression of JAK2 inhibitor \\
\hline 0.833 & 0.003 & Inhibitor of alcohol dehydrogenase $\left(\mathrm{NADP}^{+}\right)$ \\
\hline 0.829 & 0.002 & Inhibitor of leukotriene-B4 20-monooxygenase \\
\hline 0.828 & 0.005 & Alkane 1-monooxygenase inhibitor \\
\hline 0.822 & 0.005 & Inhibitor of oxidoreductase \\
\hline 0.820 & 0.016 & Methylenetetrahydrofolate reductase inhibitor (NADPH) \\
\hline 0.817 & 0.005 & Substrate of CYP1A1 \\
\hline 0.815 & 0.003 & Inhibitor of $\beta$-carotene $15.15^{\prime}$-monooxygenase \\
\hline 0.815 & 0.004 & Histidine kinase inhibitor \\
\hline 0.809 & 0.002 & 2-Enoate reductase inhibitor \\
\hline 0.809 & 0.013 & 5 Hydroxytryptamine release stimulant \\
\hline 0.808 & 0.003 & Inhibitor of nitrite reductase [NAD $(\mathrm{P}) \mathrm{H}]$ \\
\hline 0.806 & 0.004 & UGT1A6 substrate \\
\hline 0.805 & 0.017 & Mucous membrane protector \\
\hline 0.802 & 0.016 & Gluconate 2-dehydrogenase inhibitor \\
\hline 0.801 & 0.002 & Inhibitor of Glycerol dehydrogenase $\left(\mathrm{NADP}^{+}\right)$ \\
\hline 0.797 & 0.002 & CYP1A2 inducer \\
\hline 0.797 & 0.003 & Inhibitor of histamine release \\
\hline
\end{tabular}




\subsection{Antibacterial Activity}

\subsubsection{Determination of Minimum Inhibitory Concentration (MIC)}

The flavonoids flavone, 3-hydroxyflavone, 5-hydroxyflavone and 6-hydroxyflavone have antibacterial activity against Gram positive and Gram negative strains, evidenced by the determination of the corresponding minimum inhibitory concentration $\left(\mathrm{MIC}_{50}\right.$ ), which was $100 \mu \mathrm{g} / \mathrm{mL}$ for flavone and $200 \mu \mathrm{g} / \mathrm{mL}$ for the hydroxylated derivatives (Tables 5 and 6 ).

Table 5. Antibacterial activity $(\mu \mathrm{g} / \mathrm{mL})$ of flavonoids flavone, 3-hydroxyflavone, 3-hydroxyflavone and 3-hydroxyflavone against Gram-positive strains.

\begin{tabular}{|c|c|c|c|c|c|c|}
\hline $\begin{array}{ll} & \text { Test Group } \\
\end{array}$ & Flavone & 3-Hydroxyflavone & 5-Hydroxyflavone & 6-Hydroxyflavone & Chloramphenicol & DMSO \\
\hline B. subtilis CCТ 0516 & $>200$ & 200 & $>200$ & $>200$ & 100 & + \\
\hline S. aureus ATCC 25619 & 100 & 100 & 200 & 200 & 100 & + \\
\hline S. aureus ATCC 25925 & 200 & 200 & $>200$ & $>200$ & 100 & + \\
\hline
\end{tabular}

Table 6. Antibacterial activity $(\mu \mathrm{g} / \mathrm{mL})$ of flavonoids flavone, 3-hydroxyflavone, 5-hydroxyflavone and 6-hydroxyflavone against Gram-negative strains.

\begin{tabular}{|c|c|c|c|c|c|c|}
\hline $\begin{array}{ll}\text { Bacteria } & \text { Test Group } \\
\end{array}$ & Flavone & 3-Hydroxyflavone & 5-Hydroxyflavone & 6-Hydroxyflavone & Chloramphenicol & DMSO \\
\hline P. aeruginosa ATCC 8027 & 200 & 200 & $>200$ & $>200$ & 100 & + \\
\hline P. aeruginosa ATCC 23243 & 50 & 200 & 200 & 200 & 100 & + \\
\hline E. coli ATCC 2536 & 100 & 100 & 200 & $>200$ & 100 & + \\
\hline E. coli 101 & 100 & 200 & 200 & 200 & 100 & + \\
\hline E. coli 103 & 25 & 200 & $>200$ & $>200$ & 100 & + \\
\hline E. coli 104 & 200 & 100 & 200 & $>200$ & 100 & + \\
\hline E. coli 105 & 25 & 200 & 200 & $>200$ & 100 & + \\
\hline E. coli 108 & 200 & 100 & 25 & 200 & 100 & + \\
\hline
\end{tabular}

\subsubsection{Determination of Minimum Bactericidal Concentration (MBC)}

Once the antibacterial activity of flavonoids was proven, it remained to determine whether this was a result of bactericidal or bacteriostatic action. The minimum bactericidal concentration of flavone was $200 \mu \mathrm{g} / \mathrm{mL}$ against the strains of P. aeruginosa ATCC 8027, S. aureus ATCC 25619, and E. coli 104. For the other flavonoids, it was determined that against the strains tested, the antimicrobial action was bacteriostatic.

\subsection{Oxidant and Antioxidant Activity Assay}

2.3.1. Evaluation of the Antioxidant Potential of these Flavonoids in Human Erythrocytes in the Presence of Reactive Oxygen Species

It was decided to evaluate antioxidant activity for concentrations of 1 to $200 \mu \mathrm{g} / \mathrm{mL}$, and from the analysis of the results expressed in Figure 2a- $d$ it was possible to assign antioxidant effect to the flavonoids flavone, 3-hydroxyflavone, 5-hydroxyflavone and 6-hydroxyflavone in all concentrations evaluated; checking reductions in hemolysis as induced by hydrogen peroxide $\left(\mathrm{H}_{2} \mathrm{O}_{2}\right)$, as compared to the control group $\left(\mathrm{Hb}+\mathrm{H}_{2} \mathrm{O}_{2}\right)$. 

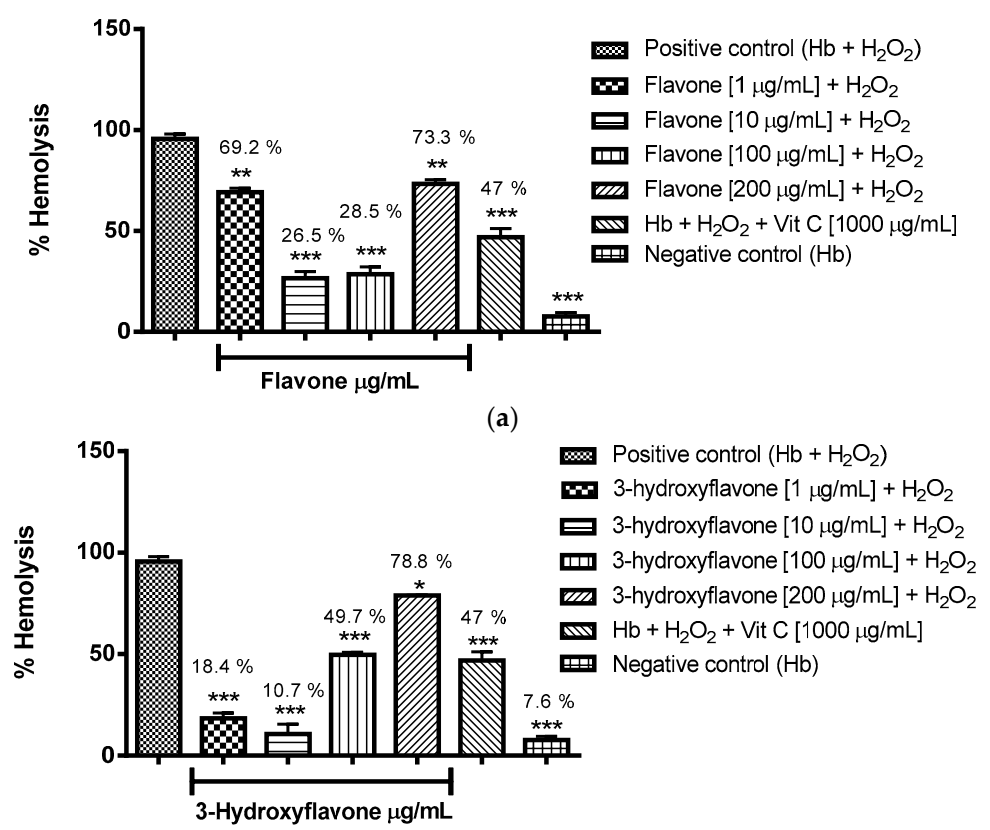

(b)

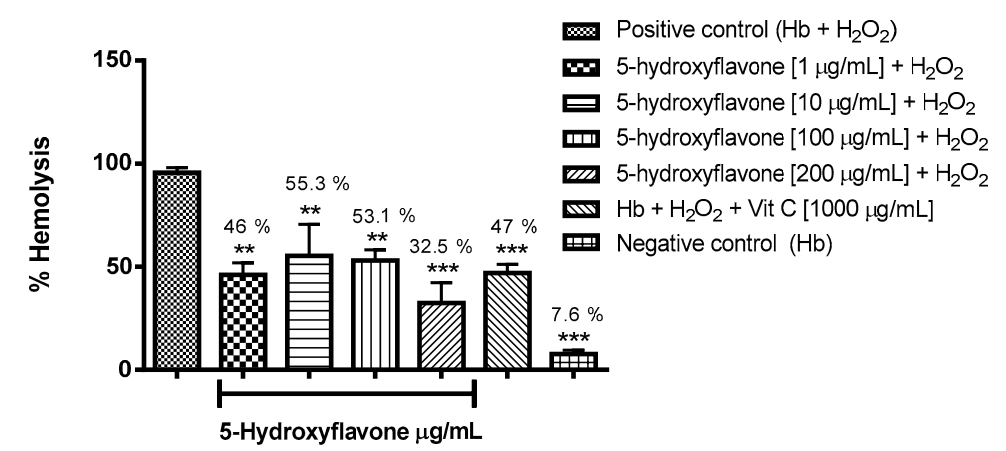

(c)

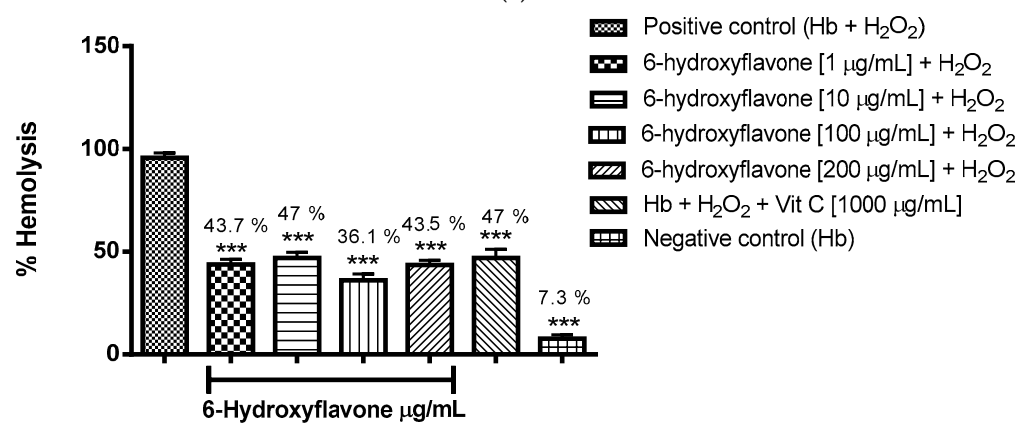

(d)

Figure 2. Antioxidant activity of flavonoids flavone (a), 3-hydroxyflavone (b), 5-hydroxyflavone (c) and 6-hydroxyflavone (d) against hemolysis induced by hydrogen peroxide in blood of type O+. The results are expressed as a percentage of the average in comparison to the positive control group $(\mathrm{Hb}+$ $\left.\mathrm{H}_{2} \mathrm{O}_{2}\right)$. Analysis by ANOVA followed by Dunnett post-test. ${ }^{*} p<0.05,{ }^{* *} p<0.01,{ }^{* * *} p<0.001(n=3)$.

2.3.2. Assessment of the Oxidant and Antioxidant Potential of Flavonoids in Human Erythrocytes in the Presence of Phenylhydrazine

The oxidizing power of the flavonoids was verified through the percentage of formation of methemoglobin/hemoglobin using incubation with type $\mathrm{O}$ cells. It can be concluded that flavone, 3-hydroxyflavone, 5-hydroxyflavone and 6-hydroxyflavone did not induce oxidation in comparison to the negative control group (Hb-hemoglobin), as expressed in Figures 3a, 4a, 5a and 6a. 


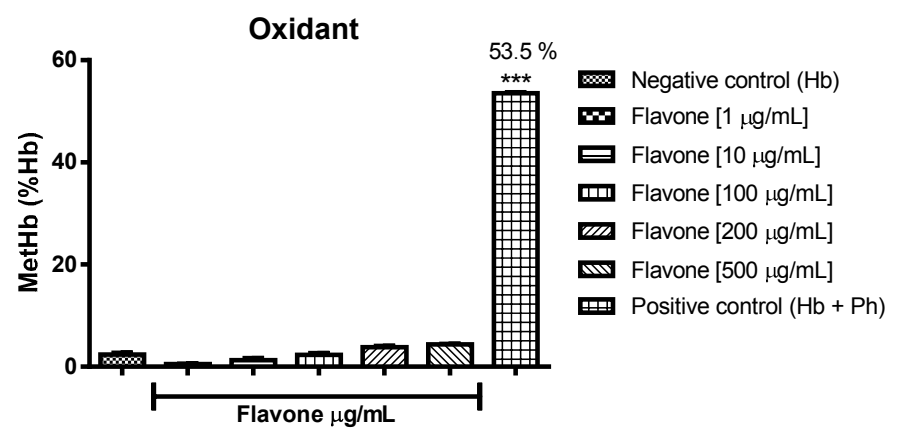

(a)

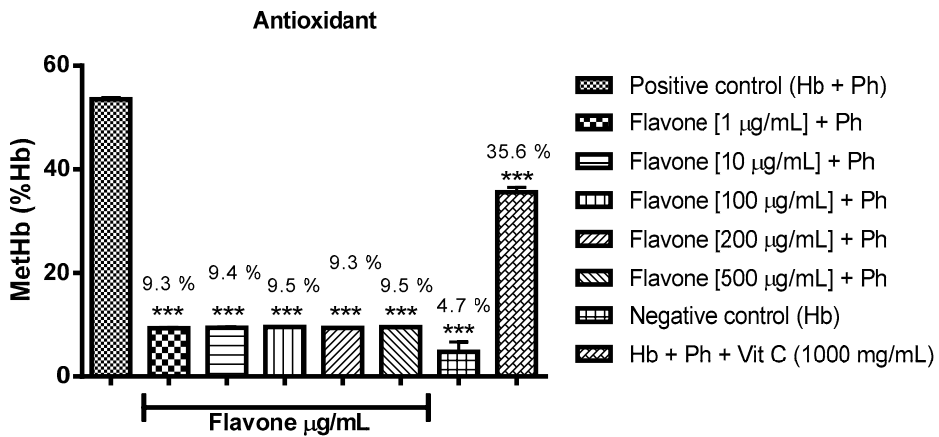

(b)

Figure 3. Oxidant (a) and antioxidant (b) effects of flavone on human erythrocytes. The results are expressed as a percentage of the average formation of methemoglobin ( $\mathrm{MetHb}$ ) compared to the negative control (oxidant) and positive control (antioxidant) groups. Analysis by ANOVA followed by Dunnett post-test. ${ }^{* * *} p<0.001(n=3)$.

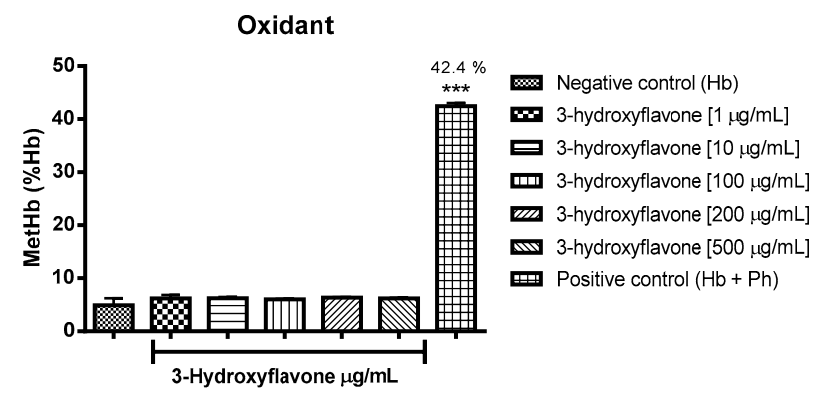

(a)

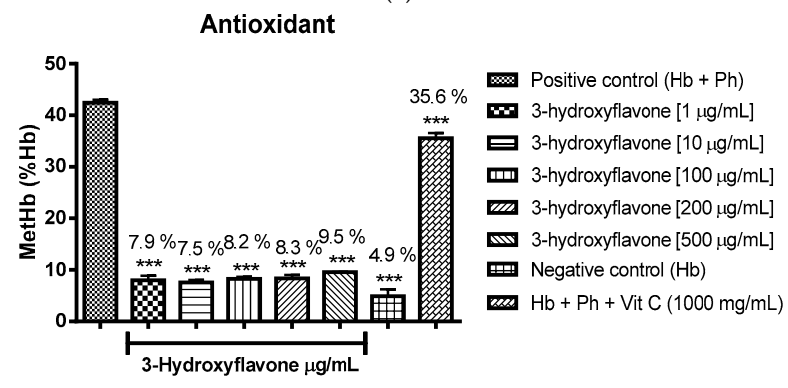

(b)

Figure 4. Oxidant (a) and antioxidant (b) effects of 3-hydroxyflavone on human erythrocytes. The results are expressed as a percentage of the average formation of methemoglobin (MetHb) compared to the negative control (oxidant) and positive control (antioxidant) groups. Analysis by ANOVA followed by Dunnett post-test. ${ }^{* *} p<0.001(n=3)$. 
Oxidant

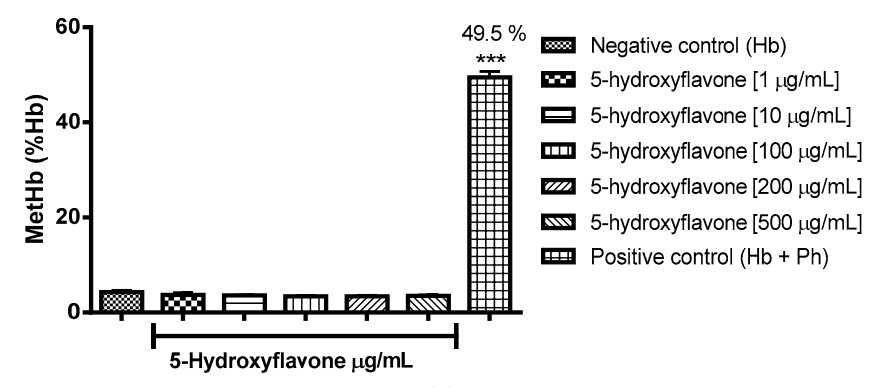

(a)

Antioxidant

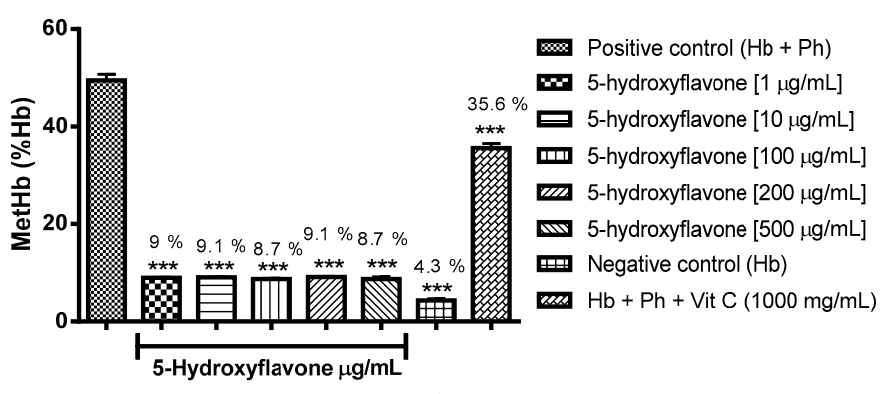

(b)

Figure 5. Oxidant (a) and antioxidant (b) effects of 5-hydroxyflavone on human erythrocytes. The results are expressed as a percentage of the average formation of methemoglobin ( $\mathrm{MetHb}$ ) compared to the negative control (oxidant) and positive control (antioxidant) groups. Analysis by ANOVA followed by Dunnett post-test. ${ }^{* * *} p<0.001(n=3)$.
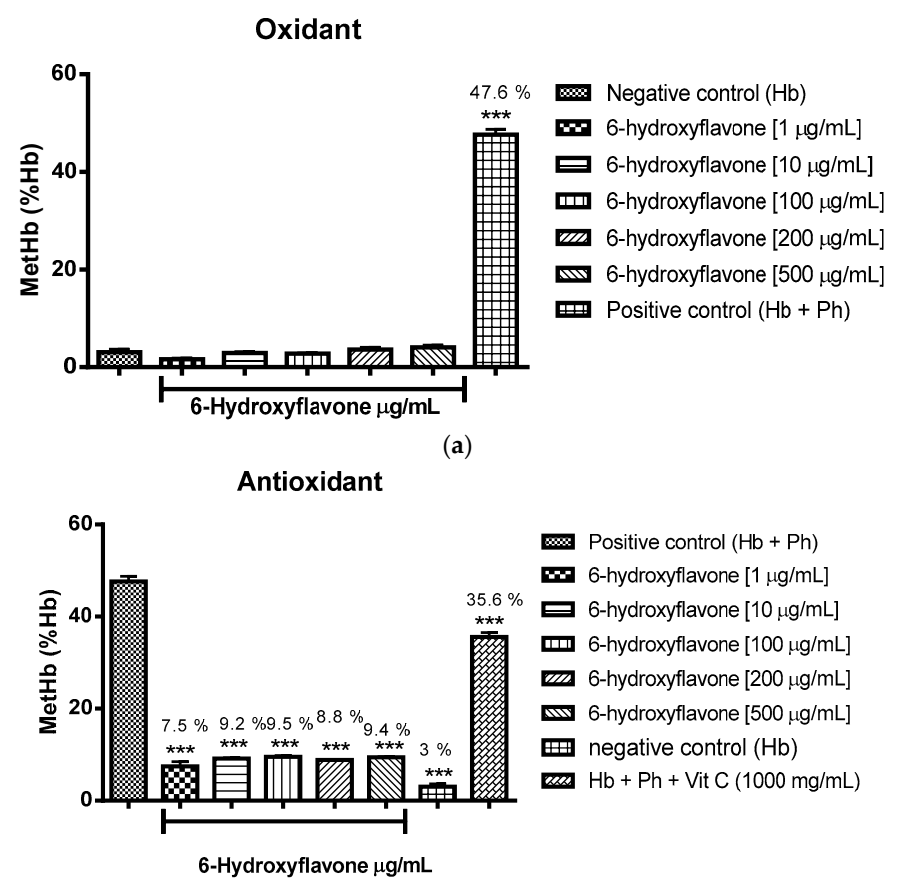

(b)

Figure 6. Oxidant (a) and antioxidant (b) effects of 6-hydroxyflavone on human erythrocytes. The results are expressed as a percentage of the average formation of methemoglobin (MetHb) compared to the negative control (oxidant) and positive control (antioxidant) groups. Analysis by ANOVA followed by Dunnett post-test. ${ }^{* * *} p<0.001(n=3)$. 
As to the effect associated with antioxidant flavonoids, this was found through statistically significant reductions in the formation of methemoglobin/hemoglobin against phenylhydrazine as an oxidizing agent, the effect was promoted by all concentrations tested and compared to the positive control group $(\mathrm{Hb}+\mathrm{Ph}$ ) (Figures $3 b, 4 b, 5 b$ and $6 b)$, performing even better than vitamin $\mathrm{C}$.

It turns out that the flavonoids not only induces oxidation of hemoglobin to methemoglobin, but also protect against oxidation caused by erythrocyte phenylhydrazine.

\section{Discussion}

PASS revealed various biological possibilities: probable agonist action for cell membrane integrity and inhibition against membrane permeability; probable inhibition of kinases, antimutagenic activity and metabolic influence on cytochrome P450 enzymes, both as substrate and as inducer; in addition: flavone, 5-hydroxyflavone and 6-hydroxyflavone were assigned inhibition of peroxidase and oxidoreductase, and vasoprotective potential.

The flavonoids presented possible antitumor activity; flavone, 5-hydroxyflavone and 6-hydroxyflavone had predicted antitumor potential via inhibition of the Pin1 gene, and all three hydroxylated derivatives showed theoretical TP53 gene increases.

There are many mechanisms proposed for the effects promoted by flavonoids during the initiation and promotion stages of carcinogenicity; the principal effects are given as follows: down regulation of mutant p53 protein, cell cycle arrest, tyrosine kinase inhibition, inhibition of heat shock proteins, estrogen receptor binding capacity and inhibition of Ras proteins expression [34].

The Pin1 gene (Peptidyl-prolyl cis-trans isomerase NIMA-interacting 1) has demonstrated certain functional polymorphisms associated with cancer risk; the gene regulates conformation of phosphorylation sites, and it has been involved in multiple oncogenic signaling pathways as a critical catalyst. TP53 is a tumor suppressor gene known as "the cellular gatekeeper of growth and division", it acts controlling cellular growth and by inducing important genes in cycle arrest and apoptosis following DNA damage [35,36].

When protein kinases (PKs) are deregulated pathological conditions may originate defects in phosphorylation leading to uncontrolled cell division, inhibition of apoptosis, and other abnormalities. Knowing this, the inhibition of these enzymes is as a promising strategy against cancer, and various studies have shown that flavonoids are capable of inhibiting a number of protein kinases from differing cellular signal pathways, such as: tyrosine kinase (PTK), serine/threonine kinases, and phosphatidylinositol 3-kinase (PI3K) [37].

One of the targets that flavones can interact with is phosphatidylinositol 3-kinase. The PI3K pathway is one of the most frequently activated signaling routes in human cancers, occurring in $30-50 \%$ of the cancerous cells [38]. The PI3K is an enzyme generally regulated by growth factors; when activated, PI3K adds a phosphate group to phosphatidylinositol 4,5-bisphosphate (PIP2), generating phosphatidylinositol 3,4,5-triphosphate (PIP3), an intra-cellular messenger. Akt, also known as protein kinase B (PKB), interacts with PIP3 and translocates to the plasma membrane, Akt is activated downstream of PI3K and has multiple targets that are extremely important in the balance control between survival and apoptosis. Some studies indicate in cancer patients, that activation of the $\mathrm{PI} 3 \mathrm{~K} /$ Akt pathway occurs because its components are targeted for amplification, mutation and translocation more frequently than any other pathway $[39,40]$.

Lee et al. [41] demonstrated that apigenin (4',5,7-trihydroxyflavone), a natural flavonoid, inhibits HGF-induced (Hepatocyte growth factor) which controls invasive growth of MDA-MB-231 human breast cancer cells, including their motility, scattering, migration, and invasion; through blocking the PI3K/Akt pathway. Woo et al. [42] also testing natural flavonoids investigated the effect of chrysin (5,7-dihydroxyflavone) on the apoptotic pathway in U937 human promonocytic cells; it was shown that chrysin induces apoptosis in association with the activation of caspase 3 , and the Akt signal pathway plays a decisive role in chrysin-induced apoptosis in U937 cells. In the same study, they 
showed apoptosis increases when Akt phosphorylation in U937 cells was inhibited by the specific PI3K inhibitor; significantly LY294002, enhanced apoptosis.

The flavones tested in this work present certain structural similarities with the compounds mentioned above, and have also demonstrated a theoretical inhibitory effect on protein kinases; able to interact with PI3K/Act pathway and ERK (extracellular signal regulated kinase).

Flavone was found to have an antimicrobial effect, with an MIC of $100 \mu \mathrm{g} / \mathrm{mL}$, against the strains E. coli 2536, E. coli 101, 103 E. coli, E. coli 105, P. aeruginosa ATCC 23243, and S. aureus ATCC 25619, Gram positive and Gram negative bacteria with an MIC of $200 \mu \mathrm{g} / \mathrm{mL}$ for the hydroxylated flavone derivatives, especially 3-hydroxyflavone that inhibited the growth of all bacterial strains tested (Tables 5 and 6). This noted wider effect can be attributed to the presence of a hydroxyl in position 3 of the benzopyran carbon ring of the flavonoid, next to the carbonyl. It should also be noted that flavone and 5-hydroxyflavone at a concentration of $25 \mu \mathrm{g} / \mathrm{mL}$ showed antibacterial effect on strains of E. coli $(103,105$, and 108). This concentration was well below that used for the standard drug chloramphenicol $(100 \mu \mathrm{g} / \mathrm{mL})$.

With regard to the antibacterial effect, flavone presented a bactericidal concentration of $200 \mu \mathrm{g} / \mathrm{mL}$ against strains of P. aeruginosa ATCC 8027, S. aureus ATCC 25619 and E. coli 104, while the other flavonoids were bacteriostatic at $200 \mu \mathrm{g} / \mathrm{mL}$.

Ríos \& Recio [43] posit avoiding evaluation tests for antibiotic activity with extract concentrations of greater than $1000 \mu \mathrm{g} / \mathrm{mL}$, or $100 \mu \mathrm{g} / \mathrm{mL}$ for isolated substances. Antimicrobial potential is interesting when detected at concentrations below $100 \mu \mathrm{g} / \mathrm{mL}$ for extracts, or $10 \mu \mathrm{g} / \mathrm{mL}$ for active ingredients. To assign positive activity for excessively high concentrations is to be avoided. Following this evaluation criterion, the antibiotic activity of flavonoids is to be understood as moderate.

In QSAR evaluation study with flavonoids it was found that good antibacterial activity structure requirements include hydroxyl groups in positions $C-3, C-5, C-7$ and C- $3^{\prime}$, the C-2, 3 unsaturated double bond and a carbonyl group at $\mathrm{C}-4$ is essential, while the presence of the hydroxyl group on C-6, can lower the antibacterial activity [44]. The hydroxyl group normally works as a lead donor $\mathrm{H}$, the presence of an electron donor group in conjunction with the group $\alpha, \beta$-unsaturated, can promote electronic interactions, which decrease your bactericidal effect, observing due to the presence of variations in the structure of the compound and the replace mode [44,45]. Still, lipophilic flavonoids can also disrupt microbial membranes [34], so the high lipophilicity of flavone results in increased hydrophobic interaction by promoting a better antibacterial effect.

Lovewell et al. [46] identified for the first time that the PI3K/Akt pathway mediates the motility-driven phagocytosis of $P$. aeruginosa, and the gradual loss of bacterial flagellar motility is proportional to the degree of Akt activation in host cells, in parallel to the phagocytic susceptibility. This means that therapies using PI3K/Akt pathway inhibitors could act as bactericides, preventing phagocytosis and motility.

Since the compounds present in this work had a theoretical effect on kinases, they could act in such a way on P. aeruginosa. Flavonoids are able to modulate the activity of enzymes and affect the behavior of many cellular systems, exercising beneficial effects on the body [47]. Several studies have identified and attributed to flavonoids antioxidant potential. Ghasemzadeh et al. [48]. Reported that the total phenolic compounds and flavonoids in Halia bara possess potent antioxidant activities.

Zhao [49] suggests that the action of propolis comes from its flavonoids' ability to interact, having lipophilic characteristics, with the bacterial plasma membrane, causing disorder. Perhaps it is through this mechanism that flavone acts in promoting bactericidal activity, since it is among the tested, the flavonoid featuring a greater $\operatorname{cLog} P(3.74)$, giving greater lipid solubility and allowing the same to cross the membrane. However, other mechanisms might justify the antibacterial action observed, such as inhibition of DNA gyrase, an enzyme responsible for separating the double helix during DNA replication [50,51].

To combat oxidative stress, cells and tissues have enzymatic and non-enzymatic antioxidant defense systems. However, under conditions of extreme stress such endogenous systems are not 
sufficient; making the support provided by antioxidants of exogenous origin necessary [31]. In this context, the red blood cells enjoy wide use in studies of oxidative stress, being a simple representative cell model. Their membranes possess the functions of other cells, such as active and passive transport and electrochemical gradients. Hydrogen peroxide $\left(\mathrm{H}_{2} \mathrm{O}_{2}\right)$, induces changes in the form of these cells, characterized by bubbles or bulges on the cell membrane, which indicate oxidative damage [52].

From analysis of the results expressed in Figure 2a-d it was possible to assign non-concentration dependent antioxidant effect to flavone, 3-hydroxyflavone, 5-hydroxyflavone and 6-hydroxyflavone in all concentrations evaluated using reductions in hemolysis as induced by hydrogen peroxide $\left(\mathrm{H}_{2} \mathrm{O}_{2}\right)$, this as compared to the control group $\left(\mathrm{Hb}+\mathrm{H}_{2} \mathrm{O}_{2}\right)$, in some situations these flavonoids showed more antioxidant potential than vitamin $\mathrm{C}$.

Another protocol used to investigate the antioxidant potential of these flavonoids was the erythrocyte oxidative agent phenylhydrazine, revealing the percentage of methemoglobin formation in relation to hemoglobin $(\% \operatorname{metHb} / \mathrm{Hb})$.

The Figures 3a, 4a, 5a and 6a show respectively that flavone, 3-hydroxyflavone, 5-hydroxyflavone and 6-hydroxyflavone did not oxidize red blood cells when compared to the negative control group $(\mathrm{Hb})$, and in turn presented antioxidant activity in the presence of phenylhydrazine, seeing the reduced percentages of methemoglobin formation in relation to hemoglobin $(\%$ metHb/Hb) (Figures $3 b, 4 b, 5 b$ and $6 \mathrm{~b})$ as compared to the positive control group $(\mathrm{Hb}+\mathrm{Ph})$.

The search for new antioxidant agents is important because the oxidative stress causes peroxidation of membrane lipids, aggression to proteins in tissues and membranes, enzymes, carbohydrates and DNA. These damages have been related to the pathogenicity of some diseases, such as atherosclerosis, neuronal degeneration, cancer, rheumatoid arthritis, diabetes mellitus, inflammation and vascular disease [53-55].

\section{Materials and Methods}

\subsection{Flavonoids}

The flavonoids flavone, 3-hydroxyflavone, 5-hydroxyflavone and 6-hydroxyflavone were kindly provided by Prof. Dr. José Maria Barbosa Filho of the Phytochemical Laboratory of Natural Products, of the graduate program in Natural and Synthetic Bioactive Products-CCS/UFPB, having been purchased from Sigma-Aldrich ${ }^{\circledR}$ (St. Louis, MO, USA). The flavonoids were solubilized in DMSO the concentration of $10 \mathrm{mg} / \mathrm{mL}$.

\subsection{Bacterial Species}

We evaluated Gram positive bacteria and Gram negative bacteria from the Tropical Cultures Collection (CCT, Campinas, SP, Brazil), American Type Culture Collection (ATCC, Manassas, VA) and of clinical origin, being: Bacillus subtilis CCT 0516, Pseudomonas aeruginosa ATCC 8027, Pseudomonas aeruginosa ATCC 23243, Staphylococcus aureus ATCC 25619, Staphylococcus aureus ATCC 25925, Escherichia coli 2536, Escherichia coli 101, Escherichia coli 103, Escherichia coli 104, Escherichia coli 105 and Escherichia coli 108.

\subsection{Culture Medium}

The bacteria were grown in Luria Bertani (LB), consisting of: yeast extract (Difco Franklin Lakes, NJ, USA) $10 \mathrm{~g}$, tryptone (Difco) $5 \mathrm{~g}$ and $\mathrm{NaCl}$ (Vetec Química Fina Ltda, Duque de Caxias, RJ, Brazil), $10 \mathrm{~g}$, solubilized in distilled water and autoclaved at $121^{\circ} \mathrm{C}, 1 \mathrm{~atm}$, for $15 \mathrm{~min}$.

\subsection{Preparation of the Bacterial Inoculum}

Micro-organisms were inoculated in LB sterile medium and incubated at $37^{\circ} \mathrm{C}$ for $24 \mathrm{~h}$. The bacterial suspension was adjusted according to the standard range of $0.5 \mathrm{McF}$ arland, containing $1-5 \times 10^{8} \mathrm{CFU} / \mathrm{mL}[56,57]$. 


\subsection{Human Erythrocytes}

The human erythrocytes of blood types A, B, O, with Rh positive and negative were obtained from bags containing concentrated of erythrocytes that would not be used for transfusion, from the Transfusional Unit of the University Hospital Lauro Wanderley-UFPB. The handling and disposal of erythrocytes followed the hospital safety standards. The experimental protocols were approved by the Research Ethics Committee/CCS/UFPB.

\subsection{In Silico Study-PASS Online}

Prediction of the spectrum of activity for substances using (PASS) online was performed to assess the overall biological potential of the organic molecule for the human organism. Based on the structures of organic compounds, the program provides simultaneous predictions of many types of biological activity. Through molecular structural analysis, the program provides a set of likely activities, giving various facets of biological action for a compound by means of interpretation of the Pa rates (probability "to be active") and Pi (probability "to be inactive") [31].

\subsection{Antibacterial Activity}

\subsubsection{Determination of Minimum Inhibitory Concentration (MIC)}

Determination of MIC was performed using microdilution technique, in 96 well "U" plates as determined by Gerhardt et al. [58]. LB medium $(160 \mu \mathrm{L})$ was distributed into all wells. Subsequently, $40 \mu \mathrm{L}$ of solution $(10 \mathrm{mg} / \mathrm{mL})$ of each of the flavonoids was added and then half serial dilution was performed $(200 ; 100 ; 50 ; 25 ; 12.5$ and $6.25 \mu \mathrm{g} / \mathrm{mL}$ ). Finally, $10 \mu \mathrm{L}$ of each bacterial suspension (B. subtilis CCT 0516, P. aeruginosa ATCC 8027, P. aeruginosa ATCC 23243, S. aureus ATCC 25619, S. aureus ATCC 25925, E. coli 2536, E. coli 101, E. coli 103, E. coli 104, E. coli 105, E. coli 108) were added to the wells. The licensed antimicrobial chloramphenicol $(100 \mu \mathrm{g} / \mathrm{mL})$, and the vehicle DMSO were tested too. The plates were incubated at $37^{\circ} \mathrm{C}$ for $24 \mathrm{~h}$ and bacterial growth was evidenced after addition of $20 \mu \mathrm{L}$ of sodium resazurin solution $0.01 \%(w / v)$ (SIGMA), a colorimetric metabolic activity indicator. The MICs for the products tested were regarded as being the lowest concentration which completely inhibited bacterial growth when compared to the control group, being checked for maintaining the blue color of the resazurin. The tests were carried out in duplicate and the result was the arithmetic mean of the MIC obtained in two trials.

\subsubsection{Determination of Minimum Bactericidal Concentration (MBC)}

Determination of MBC was performed plating de MIC dilution and at least two of the more concentrated flavonoids dilution on LB medium plus agar $1.5 \%$. The plates were incubated at $37^{\circ} \mathrm{C}$ for $24 \mathrm{~h}$ and bacterial growth was evaluated. The MBCs for the products tested were considered the lowest concentration in which no bacterial growth is observed.

\subsection{Oxidant and Antioxidant Activity Assays}

4.8.1. Evaluation of the Antioxidant Potential of Flavonoids in Human Erythrocytes in the Presence of Reactive Oxygen Species

The experiment was carried out in accordance with a study by Bilton et al. [59], with minor modifications. Each flavonoid (1, 10, 100, 200 and $500 \mu \mathrm{g} / \mathrm{mL}$ ) was incubated with $2 \mathrm{~mL}$ of a $0.5 \%$ erythrocyte suspension in $0.9 \% \mathrm{NaCl}$ for $4 \mathrm{~h}$ at $25 \pm 2{ }^{\circ} \mathrm{C}$ in the presence of $\mathrm{H}_{2} \mathrm{O}_{2}(40 \mathrm{mM})$. A erythrocyte suspension was used as negative control ( $0 \%$ cell hemolysis), and a erythrocyte suspension in the presence of $\mathrm{H}_{2} \mathrm{O}_{2}(40 \mathrm{mM})$ as positive control $(100 \%$ hemolysis $)$. Vitamin $\mathrm{C}(1000 \mu \mathrm{g} / \mathrm{mL}) \mathrm{was}$ used as standard. After $4 \mathrm{~h}$, the samples were centrifuged at $2500 \mathrm{rpm}$ for $5 \mathrm{~min}$ and hemolysis was quantified by reading an aliquot of the supernatant solution using spectrophotometry at $540 \mathrm{~nm}$ [60]. 
All experiments were performed in triplicate and the results expressed as percentage of hemolysis in comparison to the positive control group $\left(\mathrm{Hb}+\mathrm{H}_{2} \mathrm{O}_{2}\right)$.

4.8.2. Assessment of Oxidant and Antioxidant Potential for Flavonoids in Human Erythrocytes in the Presence of Phenylhydrazine

To investigate the oxidizing potential of the flavonoids a $30 \%$ erythrocytes suspension in PBS (11.35 $\mathrm{g} \mathrm{NaH}_{2} \mathrm{PO}_{4} \cdot 2 \mathrm{H}_{2} \mathrm{O}, 24.36 \mathrm{~g} \mathrm{Na}_{2} \mathrm{HPO}_{4}$ and $7.18 \mathrm{~g} \mathrm{NaCl}$ to $1 \mathrm{~L}$, $\mathrm{pH} 7.4$ ) supplemented with glucose (200 mg/dL), pH 7.6 was prepared. Each flavonoid $(1,10,100,200,500 \mu \mathrm{g} / \mathrm{mL}$ ) were then added to $2 \mathrm{~mL}$ of erythrocyte suspension and incubated for a period of $1 \mathrm{~h}$ under slow and steady stirring $(100 \mathrm{rpm})$ at $25 \pm 2{ }^{\circ} \mathrm{C}$. Then the samples were centrifuged at $2500 \mathrm{rpm}$ for $5 \mathrm{~min}$ and the percentage of methemoglobin $(\mathrm{metHb})$ in relation to total hemoglobin $(\mathrm{Hb})$ was quantified by spectrophotometry at $630 \mathrm{~nm}$ and $540 \mathrm{~nm}$, respectively. The percentage of metHb formed was compared to values obtained in the presence the phenylhydrazine ( $\mathrm{Ph})$, a proven oxidizing agent [61].

To investigate the antioxidant potential, after the incubation period of $1 \mathrm{~h}$, for the step described above, we added $1 \mathrm{mmol} / \mathrm{L}$ of phenylhydrazine. The solutions were aerated and kept under constant and slow agitation (100 rpm) for another $20 \mathrm{~min}$ to $25 \pm 2{ }^{\circ} \mathrm{C}$. After this period, the samples were centrifuged at $2500 \mathrm{rpm}$ for $5 \mathrm{~min}$, diluted in phosphate buffer $\left(9 \mathrm{~g} \mathrm{Na}_{2} \mathrm{HPO}_{4} \cdot 12 \mathrm{H}_{2} \mathrm{O} ; 5.7 \mathrm{~g} \mathrm{KH}_{2} \mathrm{PO}_{4}\right.$ to $1 \mathrm{~L}$ ), and the percentage of metHb in relation to total $\mathrm{Hb}$ was quantified by spectrophotometry at $630 \mathrm{~nm}$ and $540 \mathrm{~nm}$, respectively.

According to Camargo et al. [62], metHb values between $1.9 \%$ and $3.8 \%$ are considered normal while values above $4 \%$ are considered as high. The percentage of metHb formed was compared with the values obtained for vitamin $C(1000 \mu \mathrm{g} / \mathrm{mL})$ a proven antioxidant agent. The experiments were performed in triplicate and the results expressed as the methemoglobin formation percentage, in function of hemoglobin-metHb $(\% \mathrm{Hb})$, in comparison to the positive control group $(\mathrm{Hb}+\mathrm{Ph})[61]$.

\section{Conclusions}

According to the in silico approach, flavone, 3-hydroxyflavone, 5-hydroxyflavone and 6-hydroxyflavone present a wide range of pharmacological activities, especially those related to membrane integrity and physiology, inhibition of kinases and enzymes associated with oxidoreduction processes, anti-inflammatory, antimutagenic, antitumor and vasoprotective potential. The flavonoids presented good availability for oral administration and low theoretical risk of toxicity, (except flavone which presented mutagenic potential) which makes them potential candidates for future drugs.

Flavone and its hydroxylated derivatives exhibited moderate antibacterial activity, inhibiting the growth of standard and clinical Gram negative and Gram negative bacteria at different concentrations. Flavone was more effective in inhibiting the growth of Gram negative bacteria and showed bactericidal effects against the strains of P. aeruginosa ATCC 8027, S. aureus ATCC 25619 and E. coli 104, while the other flavonoids had bacteriostatic effect. Thus, the antibacterial effect was influenced by the electron donating group $(\mathrm{OH})$ as well as variation of its position on the benzopyran ring of the flavonoids.

The flavonoids did not promote hemoglobin oxidation and had an antioxidant effect against hydrogen peroxide, suggesting a free radical sequestering action equal to phenylhydrazine, probably interfering in the formation of methemoglobin. Research like this also helps to consolidate the use of computational chemistry in silico tools to guide new drug search and discovery protocols.

Acknowledgments: The authors wish to thank the Federal University of Paraíba for their assistance in this study, and Capes and CNPq for financing.

Author Contributions: This work was carried out in collaboration between all authors. Authors C.d.A.M., G.F.G., A.A.d.O.F., A.B.L., M.d.F.F.M.D. and H.L.F.P. designed the study, performed the statistical analysis, wrote the protocol and managed the study analyses. Author J.M.B.-F. provided the flavonoids and contributed to the realization of the review of the literature about flavonoids. Authors C.d.A.M., A.B.L., T.T.M.C. and N.T.R.d.L. managed the literature search, and wrote the first draft of the manuscript. All authors have read and approved the final manuscript.

Conflicts of Interest: The authors declare no conflict of interest. 


\section{References}

1. Chebil, L.; Anthoni, J.; Humeau, C.; Gerardin, C.; Engasser, J.M.; Ghoul, M. Enzymatic acylation of flavonoids: Effect of the nature of the substrate, origin of lipase, and operating conditions on conversion yield and regioselectivity. J. Agric. Food Chem. 2007, 55, 9496-9502. [CrossRef] [PubMed]

2. Buer, C.S.; Imin, N.; Djordjevic, M.A. Flavonoids: New roles for old molecules. J. Integr. Plant Biol. 2010, 52, 98-111. [CrossRef] [PubMed]

3. Zuanazzi, J.A.S; Montanha, J.A. "Flavonóides". In Farmacognosia: Da Planta ao Medicamento, 5th ed.; Simões, C.M.O., Schenkel, E.P., Gormann, G., Mello, J.C.P., Mentz, L.A., Petrovick, P.R., Eds.; Editora da UFRGS: Porto Alegre, Brasil, 2004; pp. 577-614.

4. Peterson, J.; Lagiou, P.; Samoli, E.; Lagiou, A.; Katsouyianni, K.; La Veccia, C.; Dwye, J.; Trichopoulos, D. Flavonoid intake and breast cancer risk: A case-control study in Greece. Br. J. Cancer 2003, 89, 1255-1259. [CrossRef] [PubMed]

5. Tsuji, P.A.; Winn, N.R.; Walle, T. Accumulation and metabolism of the anticancer flavonoid 5,7-dimethoxyflavone compared to its unmethylated analog chrysin in the Atlantic killifish. Chem. Biol. Interact. 2006, 164, 85-92. [CrossRef] [PubMed]

6. Walle, T.; TA, N.; Kawamori, T.; Wen, X.; Tsuji, P.A.; Walle, U.K. Cancer chemopreventive properties of orally bioavailable flavonoids-Methylated versus unmethylated flavones. Biochem. Pharmacol. 2007, 73, 1288-1296. [CrossRef] [PubMed]

7. Cho, N.; Choi, J.H.; Yang, H.; Jeong, E.J.; Lee, K.Y.; Kim, Y.C.; Sung, S.H. Neuroprotective and anti-inflammatory effects of flavonoids isolated from Rhus verniciflua in neuronal HT22 and microglial BV2 cell lines. Food Chem. Toxicol. 2012, 50, 1940-1945. [CrossRef] [PubMed]

8. Cooks, N.C.; Samman, S. Flavonoids: Chemistry, metabolism, cardioprotective effects, and dietary sources. J. Nutr. Biochem. 1996, 7, 66-76. [CrossRef]

9. Lee, J.C.; Lim, K.T.; Jang, Y.S. Identification of Rhus verniciflua Stokes compounds that exhibit free radical scavenging and anti-apoptotic properties. Biochim. Biophys. Acta Gen. Subj. 2002, 1570, 181-191. [CrossRef]

10. Venkatachalam, H.; Yogendra, N.; Jayashree, B.S. Synthesis, characterization and antioxidant activities of synthetic chalcones and flavones. APCBEE Proc. 2012, 3, 209-213. [CrossRef]

11. Liu, S.; Luo, X.; Li, D.; Zhang, J.; Qiu, D.; Liu, W.; She, L.; Yang, Z. Tumor inhibition and improved immunity in mice treated with flavone from Cirsium japonicum DC. Int. Immunopharmacol. 2006, 6, 1387-1393. [CrossRef] [PubMed]

12. Yang, S.F.; Yang, W.E.; Kuo, W.H.; Chang, H.R.; Chu, S.C.; Hsieh, Y.S. Antimetastatic potentials of flavones on oral cancer cell via an inhibition of matrixdegrading proteases. Arch. Oral Biol. 2008, 53, 287-294. [CrossRef] [PubMed]

13. Liu, X.H.; Liu, H.F.; Shen, X.; Song, B.A.; Bhadury, P.S.; Zhu, H.L.; Liu, J.X.; Qi, X.B. Synthesis and molecular docking studies of novel 2-chloro-pyridine derivatives containing flavone moieties as potential antitumor agents. Bioorg. Med. Chem. Lett. 2010, 20, 4163-4167. [CrossRef] [PubMed]

14. Middleton, E., Jr.; Kandaswami, C. Effects of flavonoids on immune and inflammatory cell functions. Biochem. Pharmacol. 1992, 43, 1167-1179. [CrossRef]

15. Hendriks, J.J.; Alblas, J.; Van Der Pol, S.M.; Van Tol, E.A.; Dijkstra, C.D.; De Vries, H.E. Flavonoids influence monocytic GTPase activity and are protective in experimental allergic encephalitis. J. Exp. Med. 2004, 200, 1667-1672. [CrossRef] [PubMed]

16. Jung, H.A.; Jin, S.E.; Min, B.S.; Kim, B.W.; Choi, J.S. Anti-inflammatory activity of Korean thistle Cirsium maackii and its major flavonoid, luteolin 5-O-glucoside. Food Chem. Toxicol. 2012, 50, 2171-2179. [CrossRef] [PubMed]

17. Jeon, W.K.; Lee, J.H.; Kim, H.K.; Lee, A.Y.; Lee, S.O.; Kim, Y.S.; Ryu, S.Y.; Kimc, S.Y.; Leed, Y.J.; Ko, B.S. Anti-platelet effects of bioactive compounds isolated from the bark of Rhus verniciflua Stokes. J. Ethnopharmacol. 2006, 106, 62-69. [CrossRef] [PubMed]

18. Kim, J.T.; Lee, W.S.; Kim, Y.S.; Curtis-long, M.J.; Lee, B.W.; Ryu, Y.B.; Park, K.H. Isolation of cholinesterase-inhibiting flavonoids from Morus lhou. J. Agric. Food Chem. 2011, 59, 4589-4596. [CrossRef] [PubMed] 
19. Amoros, M.; Simoes, C.M.; Girre, L.; Sauvager, F.; Cormier, M. Synergistic effect of flavones and flavonols against herpes simplex virus type 1 in cell culture. Comparison with the antiviral activity of propolis. J. Nat. Prod. 1992, 55, 1732-1740. [CrossRef] [PubMed]

20. Hayashi, K.; Hayashi, T.; Otsuka, H.; Takeda, Y. Antiviral activity of 5,6,7-trimethoxyflavone and its potentiation of the antiherpes activity of acyclovir. J. Antimicrob. Chemother. 1997, 39, 821-824. [CrossRef] [PubMed]

21. Kongkuma, N.; Tuchindaa, P.; Pohmakotra, M.; Reutrakula, V.; Piyachaturawatb, P.; Jariyawatb, S.; Suksenb, K.; Yoosookc, C.; Kasisitc, J.; Napaswadc, C. DNA topoisomerase II $\alpha$ inhibitory and anti-HIV-1 flavones from leaves and twigs of Gardenia carinata. Fitoterapia 2012, 83, 368-372. [CrossRef] [PubMed]

22. Zheng, W.F.; Tan, R.X.; Yang, L.; Liu, Z.L. Two flavones from Artemisia giraldii and their antimicrobial activity. Planta Med. 1996, 62, 160-162. [CrossRef] [PubMed]

23. Tarle, D.; Dvorzak, I. Antimicrobial activity of the plant Cirsium oleraceum (L.) Scop. Acta Pharm. Jugosl. 1990, 40, 569-571.

24. Rauha, J.P.; Remes, S.; Heinonen, M.; Hopia, A.; Kähkönen, M.; Kujala, T.; Pihlajac, K.; Vuorelaa, H.; Vuorela, P. Antimicrobial effects of Finnish plant extracts containing flavonoids and other phenolic compounds. Int. J. Food Microbiol. 2000, 56, 3-12. [CrossRef]

25. Konan, N.A.; Lincopan, N.; Collantes Díaz, I.E.; Jacysyn, J.F.; Tiba, M.M.T.; Mendes, J.G.P.A.; Bacchid, E.M.; Spira, B. Cytotoxicity of cashew flavonoids towards malignant cell lines. Exp. Toxicol. Pathol. 2012, 64, 435-440. [CrossRef] [PubMed]

26. Huber, L.S.; Rodriguez-Amaya, D.B. Flavonols and flavones: Brazilian sources and factors that influence food composition. Alim. Nutr. 2008, 19, 97-108.

27. Barril, X.; Hubbard, R.E.; Morley, S.D. Virtual screening in structure-based drug discovery. Mini Rev. Med. Chem. 2004, 4, 779-791. [CrossRef] [PubMed]

28. Kitchen, D.B.; Decornez, H; Furr, J.R.; Bajorath, J. Docking and scoring in virtual screening for drug discovery: Methods and applications. Nat. Rev. Drug Discov. 2004, 3, 935-949. [CrossRef] [PubMed]

29. Muegge, I.; Ollof, S. Advances in virtual screening. Drug Discov. Today Technol. 2006, 3, 405-411.

30. Angelo, V.; Max, D.; Markus, A.L. The challenge of predicting drug toxicity in silico. Basic Clin. Pharmacol. Toxicol. 2006, 99, 195-208.

31. Srinivas, N.; Sandeep, K.S.; Anusha, Y.; Devendra, B.N. In vitro cytotoxic evaluation and detoxification of monocrotaline (Mct) Alkaloid: An In Silico approach. Int. Invent. J. Biochem. Bioinform. 2014, 2, $20-29$.

32. Marchant, C.A. Computational toxicology: A tool for all industries. Wires Comput. Mol. Sci. 2012, 2, 424-434. [CrossRef]

33. Auld, D.S.; Diller, D.; Ho, K. Targeting signal transduction with large combinatorial collections. Drug Discov. Today 2002, 7, 1206-1213. [CrossRef]

34. Kumar, S.; Pandey, A.K. Chemistry and biological activities of flavonoids: An overview. Sci World J. 2013, 2013. [CrossRef]

35. Maruszak, A.; Safranow, K.; Gustaw, K.; Kijanowska-Haładyna, B.; Jakubowska, K.; Olszewska, M.; Styczyńska, M.; Berdyński, M.; Tysarowski, A.; Chlubek, D.; et al. PIN1 gene variants in Alzheimer's disease. BMC Med. Genet. 2009, 10, 115. [CrossRef] [PubMed]

36. Naccarati, A.; Polakova, V.; Pardini, B.; Vodickova, L.; Hemminki, K.; Kumar, R.; Vodicka, P. Mutations and polymorphisms in TP53 gene-An overview on the role in colorectal cancer. Mutagenesis 2012, 27, 211-218. [CrossRef] [PubMed]

37. Ravishankar, D.; Rajora, A.K.; Greco, F.; Osborn, H.M.I. Flavonoids as prospective compounds for anti-cancer therapy. Int. J. Biochem. Cell Biol. 2013, 45, 2821-2831. [CrossRef] [PubMed]

38. Yap, T.A.; Bjerke, L.; Clarke, P.A.; Workman, P. Drugging PI3K in cancer: Refining targets and therapeutic strategies. Curr. Opin. Pharmacol. 2015, 23, 98-107. [CrossRef] [PubMed]

39. Hennessy, B.T.; Smith, D.L.; Ram, P.T.; Lu, Y.; Mills, G.B. Exploiting the PI3K/AKT pathway for cancer drug discovery. Nat. Rev. Drug Discov. 2005, 4, 988-1004. [CrossRef] [PubMed]

40. Imai, Y.; Yamagishi, H.; Ono, Y.; Ueda, Y. Versatile inhibitory effects of the flavonoid-derived PI3K/Akt inhibitor, LY294002, on ATP-binding cassette transporters that characterize stem cells. Clin. Transl. Med. 2012, 1, 24. [CrossRef] [PubMed] 
41. Lee, W.J.; Chen, W.K.; Wang, C.J.; Lin, W.L.; Tseng, T.H. Apigenin inhibits HGF-promoted invasive growth and metastasis involving blocking PI3K/Akt pathway and $\beta 4$ integrin function in MDA-MB-231 breast cancer cells. Toxicol. Appl. Pharmacol. 2008, 226, 178-191. [CrossRef] [PubMed]

42. Woo, K.J.; Jeong, Y.J.; Park, J.W.; Kwon, T.K. Chrysin-induced apoptosis is mediated through caspase activation and Akt inactivation in U937 leukemia cells. Biochem. Biophys. Res. Commun. 2004, 325, 1215-1222. [CrossRef] [PubMed]

43. Ríos, J.L.; Recio, M.C. Medicinal plants and antimicrobial activity. J. Ethnopharmacol. 2005, 100, 80-84. [CrossRef] [PubMed]

44. Fang, Y.; Lu, Y.; Zang, X.; Wu, T.; Qi, X.J.; Pan, S.; Xu, X. 3D-QSAR and docking studies of flavonoids as potent Escherichia coli inhibitors. Sci. Rep. 2016, 6, 23634. [CrossRef] [PubMed]

45. Shakhatreh, M.A.K.; Al-Smadi, M.; Khabour, O.F.; Shuaibu, F.A.; Hussein, E.I.; Alzoubi, K.H. Study of the antibacterial and antifungal activities of synthetic benzyl bromides, ketones, and corresponding chalcone derivatives. Drug Des. Dev. Ther. 2016, 10, 3653-3660. [CrossRef] [PubMed]

46. Lovewell, R.R.; Hayes, S.M.; O'Toole, G.A.; Berwin, B. Pseudomonas aeruginosa flagellar motility activates the phagocyte PI3K/Akt pathway to induce phagocytic engulfment. Am. J. Physiol.-Lung Cell. Mol. Physiol. 2014, 306, L698-L707. [CrossRef] [PubMed]

47. Sandhar, H.K.; Kumar, B.; Prasher, S.; Tiwari, P.; Salhan, M.; Sharma, P. A Review of phytochemistry and pharmacology of flavonoids. Int. Pharm. Sci. 2011, 1, 25-41.

48. Ghasemzadeh, A.; Jaafar, H.Z.E.; Rahmat, A. Antioxidant activities, total phenolics and flavonoids content in two varieties of Malaysia Young Ginger (Zingiber officinale Roscoe). Molecules 2010, 15, 4324-4333. [CrossRef] [PubMed]

49. Zhao, J.Q.; Wen, Y.F.; Bhadauria, M.; Nirala, S.K.; Sharma, A.; Shrivastava, S.; Shukla, S.; Agrawal, O.P.; Mathur, R. Protective effects of propolis on inorganic mercury induced oxidative stress in mice. Indian J. Exp. Biol. 2009, 47, 264-269. [PubMed]

50. Cushnie, T.P.T.; Lamb, A.J. Antimicrobial activity of flavonoids. Int. J. Antimicrob. Agents 2006, 26, 343-356. [CrossRef]

51. Packer, J.F.; Luz, M.M.S. Evaluation and research method for natural products inhibitory activity. Rev. Bras. Farmacogn. 2007, 17, 102-107. [CrossRef]

52. Srour, M.A.; Bilto, Y.Y.; Juma, M. Evaluation of different methods used to measure malonyldial-dehyde in human erythrocytes. Clin. Hemorheol. Microcirc. 2000, 23, 23-30. [PubMed]

53. Jager, A.K.; Saaby, L. Flavonoids and the CNS. Molecules. 2011, 16, 1471-1485. [CrossRef] [PubMed]

54. Snijman, P.W.; Swanevelder, S.; Elizabeth Joubert, E.; Green, I.R.; Gelderblom, W.C.A. The antimutagenic activity of the major flavonoids of rooibos (Aspalathus linearis): Some dose-response effects on mutagen activationflavonoid interactions. Mutat. Res. Genet. Toxicol. Environ. Mutagen. 2007, 631, 111-123. [CrossRef] [PubMed]

55. Boersma, M.G.; Vervoort, J.; Szymusiak, H.; Lemanska, K.; Tyrakowska, B.; Cenas, N.; Segura-Aguilar, J.; Rietjens, I. Regioselectivity and reversibility of the glutathione conjugation of quercetin quinone methide. Chem. Res. Toxicol. 2000, 13, 185-191. [CrossRef] [PubMed]

56. Cleeland, R.; Squires, E. Evalution of new antimicrobials in vitro and in experimental animal infections. In Antibiotics in Laboratory Medicine, 3rd ed.; Lorian, V.M.D., Ed.; Willians \& Wilkins: Baltimore, MD, USA, 1991; pp. 739-788. ISBN 0683051687.

57. Hadacek, F.; Greger, H. Testing of antifungal natural products: Methodologies, comparatibility of results and assay choice. Phytochem. Anal. 2000, 11, 137-147. [CrossRef]

58. Gerhardt, P.; Murray, R.G.E.; Wood, W.A.; Krieg, N.R. Methods for General and Molecular Bacteriology; American Society for Microbiology: Washington, DC, USA, 1994; p. 791. ISBN 1555810489.

59. Bilton, Y.Y.; Suboh, S.; Aburjai, T.; Abdalla, S. Structure-activity relationships regarding the antioxidant effects of the flavonoids on human erythrocytes. Nat. Sci. 2012, 4, 740-747.

60. Rangel, M.; Malpezzi, E.L.A.; Susini, S.M.M.; Freitas, J.C. Hemolytic activity in extracts of the diatom Nitzschia. Toxicon 1997, 35, 305-309. [CrossRef]

61. Arbós, K.A.; Claro, L.M.; Borges, L.; Santos, C.A.; Weffort-Santos, A.M. Human erythrocytes as a system for evaluating the antioxidant capacity of vegetable extracts. Nutr. Res. 2008, 28, 457-463. [CrossRef] [PubMed] 
62. Camargo, T.M.; Alves, M.I.F.; Oliveira, S.J.; Oshima-Franco, Y. Comparative study between two methemoglobin (MHb) dosing techniques. Rev. Bras. Anal. Clin. 2007, 39, 95-98.

Sample Availability: Samples of the compounds flavone, 3-hydroxyflavone, 5-hydroxyflavone and 6-hydroxyflavone are available from the authors.

(C) 2017 by the authors. Licensee MDPI, Basel, Switzerland. This article is an open access article distributed under the terms and conditions of the Creative Commons Attribution (CC BY) license (http://creativecommons.org/licenses/by/4.0/). 